admission of air disappear, and two tubes, which might be taken for horns, issue from the anterior dorsal part of the pupa. It is at the surface of these horns that the peculiar stigmata of the pupa are seated; and I have ascertained that these orifices, to which no attention has been paid, are in considerable numbers. In the adult there is no longer any trace of these respiratory orifices at the place which they occupied in the pupa; but seven pairs of stigmata have been produced on the sides of the thorax and abdomen. This multiplicity of the stigmata coincides with the increase of the respiratory activity, denoted by the perfection of the tracheal apparatus.

Of all the organic systems the circulatory system undergoes the least important transformations. In the larvæ of the Volucelle the heart, extended in a straight line from one extremity of the body to the other, has the aortic portion very short; in the adult the heart becomes incurved to take the form of the body, and a long aorta traverses the thorax.

One of the most essential facts which springs from this inrestigation of the organization of the Volucellce is, that, at least in the Diptera, the development of certain apparatus of the adult is accomplished by a transformation of the organs of the larvæ, whilst the development of other apparatus is effected by entirely new formations.-Comptes Rendus, December 21, 1868, tome 1xvii. pp. 1231-1234.

\title{
Sphenodon, Hatteria, and Rhynchocephalus.
} By Dr. J. E. GraY.

In the first part of my ' Zoological Miscellany' published in 1831, I shortly described the skull of an Agamoid Lizard, of very peculiar structure, that I had seen in the Museum of the College of Surgeons, and $I$ proposed to regard it as a new genus, named splenoclon.

In the second part of the same work, published in 1841 , I described a Lizard, which I had received in spirits from New Zealand, under the name of Hatteria punctata.

Professor Owen, in the first volume of the "Descriptive Catalogue of the Osteological Series contained in the Museum of the Royal College of Surgeons,' published in 1853, at p. 142. nos. 662, 663, described with considerable detail the skull and the five vertebræ of the trunk of a Lacertian which he names Rhynchocephalus. The skull so named is evidently the same as that I described in the ' Zoological Miscellany,' in 1831, as Sphenodon, though the specimen is said in the Catalogue to have been presented by Prof. Owen, whose name certainly was not attached to the specimen when I described it. The specimen is still in the collection, but without the lower jaw, which was with it in 1831 .

When I described the Hatteria punctata from the specimen in spirits I had no idea that it was the same Lizard that I had described from a skull under the name of Sphenoclon; for it is not easy to observe the characters on which the genus Sphenodon was described without dissecting the animal.

A second specimen of Hatteria arriving at the British Museum, 
it was made into a skeleton, and then Dr. Günther discovered that the skull at the College of Surgeons and the skull of the Lizard I had named Hatteria were most probably the same. It should now be called Sphenodon punctatum.

I was much struck with the peculiar formation of the skull, and that induced me to describe it; but I did not then attach the great importance to its structure that Dr. Günther has since done: I only regarded it as one of the variations of structure that are found in most families. Indeed, when I consider the almost universal disinclination that zoologists have shown, almost up to this time, to admit the distinction of the two great families of Lizards, Agamidx and Iguanidæ, which are so well characterized by the teeth and geographical distribution, it would have required more than usual hardihood in 1831 , when the genus was described, to venture to form for it even a family; while an order may now be suggested for the single genus, with every probability of its being adopted - a decided proof of the progress of the science in a few years.

\section{Deep-sea Dredging.}

To the Editors of the Annals and Magazine of Natural History.

Gentlemer, - You will confer a favour on me, and, at the same time, enable me to acknowledge an act of courtesy on the part of my friend Dr. E. Perceval Wright, by inserting in the 'Annals' the following correspondence, which has already appeared in the pages of ' Scientific Opinion.'

I remain, Gentlemen, Tours very faithfully,

Kensington, Jan. 13, 1869.

G. C. Wallioh.

"To the Editors of Scientific Opinion.

"Deep-Sea Dredging and Dr. Wallich.

"SIR,-I neglected to read "Scientific Opinion' for the 16th inst. until a day or two ago, when I perceived you had done me the honour of transferring to your paper my few brief notes on 'Deep-Sea Dredging,' published in the 'Annals and Magazine of Natural History for this month. I was, however, at the same time very much grieved to find, from a footnote which you have appended to the first portion of my notes, that I have appeared to you to make little of Dr. Wallich's researches.

"I assure you and my friend Dr. Wallich that nothing was further from my thonghts. Few are, I think, better acquainted with the writings of Dr. Wallich than I am, and I yield to none in my appreciation of their value. Science has lost a great deal by the delay in the publication of the second part of his ' North-Atlantic Sea-Bed ;' and no matter what may be the discoveries of future investigators, it is to the Rosses and Wallichs that we are indebted for our truest and earliest information on the subject. 